\title{
Microbial services: challenges for microbial ecologists in a changing world
}

\author{
Hugh Ducklow* \\ The Ecosystems Center, Marine Biological Laboratory, Woods Hole, Massachusetts 02543, USA
}

\begin{abstract}
Bacteria, archaea and other microbes have dominated most biogeochemical processes on Earth for $>99 \%$ of the history of life, but within the past few decades anthropogenic activity has usurped their dominance. Human activity now impacts every ecosystem on the planet, necessitating a new socio-ecological view of ecosystem processes that incorporates human perceptions, responses, activities and ideas into ecology. The concept of ecosystem services is an important link between ecosystem processes and the social sphere. These include the provisioning, regulating, cultural and supporting benefits that ecosystems provide to enhance human well-being. Many ecosystem services are provided by microbes, initiating the concept of microbial services to society - an idea long appreciated by microbial ecologists. Experimental studies of the biodiversity-ecosystem function relationship emphasizing microbial functions are inconclusive, with increasing diversity sometimes being observed to enhance function, while at other times the opposite relationship has been found. A specific function addressing the role of bacteria in helping or hindering carbon storage in the deep ocean in response to iron fertilization is similarly uncertain. Bacteria respond positively to mesoscale iron additions in many cases, but in doing so, may retard carbon storage by decomposing sinking particles. Human exploitation of microbial services to enhance planetary sustainability must be based on focused studies of microbial processes in a human-dominated world.
\end{abstract}

KEY WORDS: Ecosystem services · Microbial services · Microbial diversity function · Sustainability · Iron fertilization

Resale or republication not permitted without written consent of the publisher

\section{INTRODUCTION}

Earth and its component ecosystems are dominated by 2 vastly different sets of processes. For at least $75 \%$ of the 4 billion year history of life, bacteria and archaea controlled elemental cycling, organic matter production and turnover and the planetary climate. In many ways, they still do. Microbes including bacteria, archaea, phytoplankton, protozoans and fungi still catalyze the major transformations of the elements, break down organic matter, and produce and consume oxygen and carbon dioxide (Smil 2003). Around half the global net primary productivity is by unicellular phytoplankton in the sea (Falkowski et al. 2000), and most of the global respiration (terrestrial and marine) is microbial. However, just within the past century $(0.00000001 \%$ of the history of life), many processes on earth have become dominated by anthropogenic activities. Vitousek et al. (1997) describe the extent of anthropogenic contributions to earth system processes. To name but a few of the examples given by those authors: over $60 \%$ of all marine fisheries are fully exploited, overexploited or depleted; over $20 \%$ of all bird species on earth have become extinct; and $50 \%$ of all accessible surface freshwater is used in human activity. The extent of human perturbation of the chemical composition of the atmosphere is well known: the $\mathrm{CO}_{2}$ concentration has increased by nearly $40 \%$ since 1750 . The transformation in the nitrogen cycle is even more striking. Human activity now 
accounts for more than half of all reactive nitrogen entering terrestrial ecosystems - an increase of over $100 \%$ in the global nitrogen cycle. Here, I suggest the importance of recognizing the shared dominance of the planet by the extreme ends of the evolutionary process: microbes and man. Space limits this to a cursory treatment, with most specific examples emphasizing bacteria. I hope the tables and references will spur readers to further investigation.

\section{ECOSYSTEM SERVICES}

With every ecosystem on earth influenced by humans (Palmer et al. 2004), it is necessary and inescapable to view human beings and their activities as integral components of ecosystems, not isolated external drivers. Humans act on and are acted upon by ecosystems, forming a complex network of feedback relationships (Fig. 1). In this model of the 'socio-ecological system' are 3 groups of interacting components: (1) climate, influenced by external drivers, biogeochemical processes and human activity; (2) ecosystems as they are typically viewed, with populations, communities and biogeochemical cycles; and (3) the social system, consisting of human communities and cultures, institutions and their actions. The climate box (Box 1) is studied by climatologists and biogeochemists; Box 2 is served by traditional ecology and most of Box 3 by sociology, economics, political science, etc. New studies of socio-ecological systems (e.g. Fig. 1) seek to unify these disciplines in a new field that includes both

The socio-ecological system

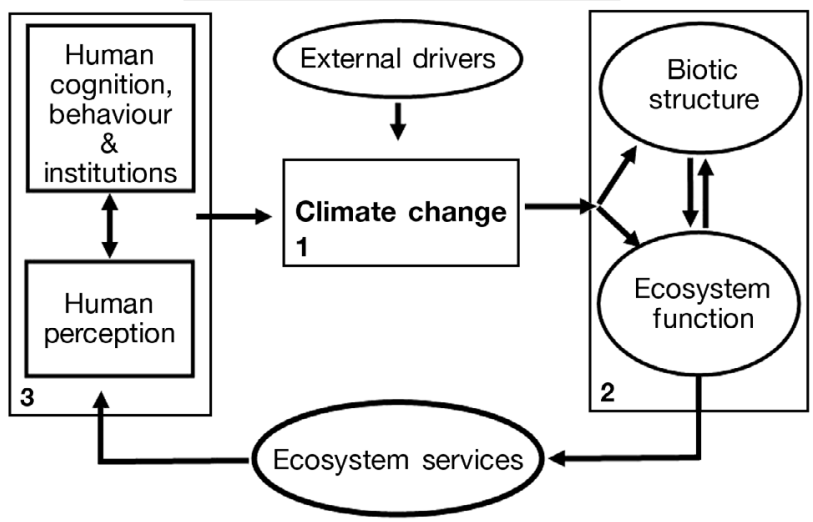

Fig. 1. A new socio-ecological framework providing the basis for exploring research questions about the interplay of human society and the environment. The right-hand side represents the domain of traditional ecological research; the left-hand side (Box 2) represents human dimensions of environmental change; the two are linked by the services provided by ecosystems (Box 3 at bottom), and by disturbances such as climate change influenced or caused by human behavior traditional and human ecology as well as the social sciences and transdisciplinary fields such as adaptive management and ecological economics (Odum 1971).

A key development in socio-ecology has been the conceptualization and assessment of 'ecosystem services' (Table 1), the functions and services supplied by 'natural' ecosystems that benefit human society (Millennium Ecosystem Assessment 2005). The 4 main categories of ecosystem services include (1) Provisioning services: generally durable goods with markets in local to global economies; (2) Regulating services: ecosystem functions essential for maintaining complex human societies on the planet; (3) Cultural services: less tangible services that enhance social institutions and enrich human well-being; and (4) Supporting services: this last category addresses the ecosystem functions that underlie and support the supply of the other services. The ecosystem services concept is important because it articulates in concrete terms the functions of the world's ecosystems as they benefit human society. The concept enables the assessment of their condition and trends in enhancement or degradation, as well as their economic valuation, which is a necessary prerequisite for analysis of the socio-ecological system. There have been several attempts, sometimes controversial, to evaluate ecosystem services in direct monetary terms (Odum 1971, Costanza et al. 1997).

\section{MICROBIAL SERVICES}

Even superficial consideration of Fig. 1 and Table 1 will suggest to microbial ecologists what we already

Table 1. Ecosystem services: 4 major types and examples

\section{Provisioning services}

- Foods (including seafood and game) and spices

- Wood and fiber (animal and vegetable fibers)

- Precursors to pharmaceutical and industrial products

- Fuel (hydropower, biomass fuels)

Regulating services

- Carbon sequestration and climate regulation

- Flood regulation

- Disease regulation

- Waste decomposition and water purification

Cultural services

- Educational

- Recreational experiences (including ecotourism)

- Aesthetic (artistic inspiration)

- Spiritual (sense of place)

Supporting services

- Soil formation

- Nutrient cycling

- Primary production 
know about the place of microbes in this scheme: many essential services and functions are carried out by microbes (even though their role is being usurped by humans in some cases). As noted above, microbes carry out most of the essential biogeochemical processes, regulate climate, water quality, atmospheric composition and perform about half the total primary production. Microbes also contribute to other services: domesticated microbes produce food, pharmaceuticals and fuels. Others even contribute to cultural values by forming natural landscape elements with aesthetic and recreational value (e.g. clean water for recreation, colored hotsprings).

This immediately suggests the concept of 'microbial services': the services supplied to humans by different groups of microbes (Table 2). Microbial services are already being exploited for commercial and environmental purposes. For example, microbial supplements are manufactured and sold as soil additives and for environmental cleanup of pollutants, as well as other environmental remediation and ecosystem restoration activities. My argument here is that microbial ecologists can contribute to socio-ecology and efforts toward achieving global sustainability by understanding the characteristics and processes of microbial communities that enable microbial services. Here I expand this argument by describing 2 examples. First I review research on the relationship between microbial (mostly bacterial) biodiversity and their ecological functions. Next I discuss the responses of bacteria and archaea during oceanic iron fertilization, and the (potential) role of marine bacteria in anthropogenic $\mathrm{CO}_{2}$ sequestration.

\section{Microbial biodiversity-ecosystem function relationships}

There is a long list of literature concerning research on the biodiversity-ecosystem function (BEF) relationship that relates species richness and other diversity measures of particular taxa in specific habitats to ecosystem functions such as productivity and grazing (e.g. Loreau et al. 2001). However, there has been little research focusing explicitly on the BEF relationship for the various groups of microbes. This is certainly due in part to the difficulty of defining microbial species and estimating their diversity (Pedros-Alio 2006). New developments in probing community composition suggest a vast untapped wealth of bacterial and archaeal species diversity (Sogin et al. 2006), yet the function of the diversity reservoir is almost entirely unknown. Does microbial diversity enhance ecosystem function? Bell et al. (2005) examined the relationship between community respiration and bacterial species diversity by creating mixtures of up to 72 culturable species in experimental microcosms over a range of species richness ( 1 to 72 species). They found a significant, positive and decelerating (log-linear) relationship between species richness and respiration rate, with apparent synergisms among different species. The overall positive BEF relationship reflected that found in many studies of higher taxa. However, a more comprehensive review of BEF studies of bacteria and other members of microbial foodwebs shows that no generalization about the size and shape of the microbial diversity-ecosystem function relationships is possible, at least given the few studies reported to date

Table 2. The major groups of microbes and examples of services they provide

\begin{tabular}{|c|c|c|}
\hline Group & Processes & Services (see Table 1) \\
\hline Heterotrophic bacteria & $\begin{array}{l}\text { Organic matter breakdown, } \\
\text { mineralization }\end{array}$ & $\begin{array}{l}\text { Decomposition, nutrient recycling, } \\
\text { climate regulation, water purification }\end{array}$ \\
\hline Heterotrophic bacteria & Extracellular polymer production & Carbon sequestration \\
\hline Photoautotrophic bacteria & Photosynthesis & Primary production \\
\hline Chemoautotrophic bacteria & $\begin{array}{l}\text { Specific elemental transformations } \\
\text { (e.g. sulfate reduction, iron oxidation) }\end{array}$ & $\begin{array}{l}\text { Nutrient recycling, climate regulation, } \\
\text { water purification }\end{array}$ \\
\hline Unicellular phytoplankton & Photosynthesis & Primary production \\
\hline Archaea & $\begin{array}{l}\text { Specific elemental transformations } \\
\text { (e.g. methanogenesis, nitrification) }\end{array}$ & $\begin{array}{l}\text { Nutrient cycling, atmosphere and } \\
\text { climate regulation }\end{array}$ \\
\hline Protozoans & $\begin{array}{l}\text { Consumption and mineralization } \\
\text { of other microbes }\end{array}$ & $\begin{array}{l}\text { Decomposition, nutrient cycling, } \\
\text { soil formation }\end{array}$ \\
\hline Fungi & $\begin{array}{l}\text { Organic matter consumption } \\
\text { and mineralization }\end{array}$ & $\begin{array}{l}\text { Decomposition, nutrient cycling, } \\
\text { soil formation }\end{array}$ \\
\hline Fungi (mycorrhizal) & Nutrient recycling & Primary production (indirect) \\
\hline Viruses & Lysis of hosts & Nutrient cycling \\
\hline
\end{tabular}


(Table 3). There is no consistent relationship, with about equal (low) numbers of positive, negative or inconclusive responses to increased diversity.

The following generalizations can be made about the state of this research: of the few studies overall, most have used cultured species. Only a few studies examined naturally occurring bacterial plus archaeal diversity and its relationship to in situ function (Reinthaler et al. 2006). Most studies are thus highly artificial, which allows isolation of the BEF relationship, but neglects other factors that may affect the relationship and masks the true diversity. Most importantly, few ecosystem processes (functions) have been analyzed. In many cases, the process was selected because it was easy to measure (e.g. bacterial biomass accumulation or production). Bacterial or community respiration is a system-level entity, but is a general consequence of many unrelated microbial taxa acting in concert. As such, it may be difficult to relate to the diversity of organisms actually carrying out the major part of the process. Examination of specific metabolic processes carried out by specific groups like methane oxidizers, nitrifiers or cellulose hydrolyzers may be a more effective approach. Microbial BEF research is a field ripe for progress.

\section{Bacterial roles in the ocean biological pump: the case of iron fertilization}

Storage of $\mathrm{CO}_{2}$ in the deep sea is facilitated by carbon fixation into biomass by phytoplankton, consumption by zooplankton and gravitational sedimentation into the deep ocean: the aggregate process termed the biological pump (Ducklow et al. 2001). Bacteria and protozoans can accelerate carbon sinking and storage by producing extracellular mucins that bind particles into larger aggregates (marine snow) that sink faster, or retard sinking and storage by decomposing the sinking materials. The net effect probably changes according to particular sets of conditions and is not well-understood (Azam \& Malfatti 2007). In large regions of the world, ocean primary production and export to depth are limited by micronutrient (iron) limitation (Martin et al. 1991). Several large ecosystem manipulation studies have been performed to examine the potential for artificial iron additions (iron fertilization) to enhance $\mathrm{CO}_{2}$ storage as a geo-engineering strategy for reducing anthropogenic $\mathrm{CO}_{2}$ accumulation in the atmosphere (Boyd et al. 2007; Table 4). The studies demonstrate convincingly that iron addition stimulates photosynthesis, macronutrient utilization and $\mathrm{CO}_{2}$ drawdown. Whether or not carbon export responds as well is less clear (Buesseler \& Boyd 2003). If iron addition does not enhance carbon export it cannot be an effective tool for climate change mitigation. Carbon storage via the biological pump is an ecosystem service that potentially has a market through trading of carbon credits. Whether the storage can be verified for trading is still not resolved. The exact role of bacteria and other microbes (their service) is uncertain.

The bacterial response has been studied in some, but not all, mesoscale iron addition experiments (Table 4). Like the BEF relationship, the results vary. The response of bacterial community composition (species composition and richness) is not conclusive, but only very few studies have examined this property. In most

Table 3. Experiments and observations relating microbial diversity and ecosystem function. Diversity is represented as the number of added species. Natural: naturally occurring species diversity in different water samples

\begin{tabular}{|lclll|}
\hline Habitat & Diversity & \multicolumn{1}{c}{ Variable } & Relationship & Source \\
\hline Freshwater & 31 & Respiration $\left(\mathrm{CO}_{2}\right)$ & + & McGrady-Steed et al. (1997) \\
Freshwater & 3 & Biomass increase & + & Naeem \& Li (1997) \\
Freshwater & High vs. Low & Productivity & 0 & Petchey et al. (1999) \\
Soil & High vs. Low & Respiration $\left(\mathrm{CO}_{2}\right)$ & + & Griffiths et al. (2000) \\
Soil & 31 & Abundance increase & + & McGrady-Steed \& Morin (2000) \\
Soil & High vs. Low & Respiration $\left(\mathrm{CO}_{2}\right)$ & 0 & Griffiths et al. (2001) \\
Freshwater & 8 & Biomass increase & 0 & Petchey et al. (2002) \\
Freshwater & 6 & Biomass increase & - & Gonzalez \& Descamps-Julien (2004) \\
Review & - & Respiration $\left(\mathrm{CO}_{2}\right)$ & + & Morin \& McGrady-Steed (2004) \\
Freshwater & 8 & Cellulose decomposition & + & Wohl et al. (2004) \\
Tree $\mathrm{H}_{2} \mathrm{O}$ & 72 & Respiration $\left(\mathrm{CO}_{2}\right)$ & + & Bell et al. (2005) \\
Freshwater & 4 & Biomass increase & + & Steiner et al. (2005) \\
Freshwater & 4 & Biomass increase & + & Steiner et al. (2006) \\
Marine & Natural & Production increase & - & Reinthaler et al. (2005) \\
Marine & Natural & Respiration increase & - & Reinthaler et al. (2005) \\
Freshwater & 4 & Decomposition & 0 & Jiang (2007) \\
Freshwater & 4 & Trophic transfer & 0 & Jiang (2007) \\
Freshwater & 4 & Biovolume increase & + & Jiang (2007) \\
& & & & \\
\hline
\end{tabular}


Table 4. Responses of bacterioplankton assemblages to mesoscale iron fertilization. +: positive response; 0: no response; —: not tested; na: not available

\begin{tabular}{|llcccc|}
\hline Study & Region/Year & Temp. $\left({ }^{\circ} \mathrm{C}\right)$ & Abund/Prod? & Community shift? & Source \\
\hline IronEx1 & Equatorial Pacific/1993 & 23 & - & - & Martin et al. (1994) \\
IronEx2 & Equatorial Pacific/1995 & 25 & + & - & Cochlan (2001) \\
SOIREE & Southern Ocean/1999 & 2 & + & - & Hall \& Safi (2001) \\
EisenEx & Southern Ocean/2000 & 4 & + & - & Arrieta et al. (2004) \\
SEEDS-1 & North Pacific/2002 & 11 & 0 & + & Suzuki et al. (2005) \\
SOFEX & Southern Ocean/2002 & -1 & + & & Oliver et al. (2004), \\
& & & & + & J.L. Oliver et al. \\
(unpubl. data) & Boyd et al. (2004), \\
SERIES & North Pacific/2002 & 13 & + & Hale et al. (2006), \\
& & & & Agawin et al. (2006) \\
EIFEX & Southern Ocean/2004 & 5 & na & na \\
SEEDS-2 & North Pacific/2004 & 10 & na & na & na \\
SAGE & Southern Ocean/2004 & 12 & na & na \\
Fee-P & Subtropical Atlantic/2004 & 21 & 0 & + & Rees et al. (2007) \\
CROZEX & Southern Ocean/2004-05 & 2 & + & & Zubkov et al. (2007) \\
\hline
\end{tabular}

studies, bacterial growth is stimulated following the phytoplankton response, suggesting that bacteria may be carbon- rather than iron-limited (Church et al. 2000). Boyd et al. (2004) calculated that most of the organic matter produced in response to iron addition in the northeast Pacific was consumed by bacteria. If the bacteria are stimulated to decompose organic matter that is produced in response to iron stimulation, their net effect will be to lower the carbon storage efficiency.

The larger issues surrounding the iron fertilization question are too complicated to review in any detail here. However, one further effect is noteworthy. If iron fertilization were effective in stimulating the biological pump, and if it were employed as a long-term, largescale strategy (this is highly uncertain; see Sarmiento \& Orr 1991), the additional input of organic matter would be consumed by heterotrophic microbes, possibly rendering the deep sea hypoxic or anoxic. Fuhrman \& Capone (1991) speculated that prolonged iron fertilization could result in large releases of $\mathrm{N}_{2} \mathrm{O}$ and methane, 2 powerful greenhouse gases. The net effect would be to enhance, not ameliorate, the anthropogenic greenhouse effect. The complex effects of iron fertilization have not borne out the initial expectations of a greenhouse panacea (Chisholm et al. 2001). As those authors stated (p. 310): “The proponents' claim that fertilization for carbon sequestration would be environmentally benign is inconsistent with almost everything we know about aquatic ecosystems."

When viewed in the context of integrated socioecological systems, including human actions and responses such as iron fertilization, the situation originally presented in Fig. 1 is much more complicated (Fig. 2). Iron fertilization provides one example of the interplay of microbial processes and human actions.
Microbes and humans together influence climate change via the ecosystem service of carbon storage, but unintended consequences like $\mathrm{N}_{2} \mathrm{O}$ production may add other feedbacks to this system. Thus, iron fertilization provides a useful case study of the complex interrelationships and feedback loops that potentially exist among climate change, microbial services and social concerns, perceptions and actions, involving microbial ecologists and the rest of society. The brevity of this article prevents a fuller examination of microbe-human-ecosystem-climate interactions and feedbacks; an enormous topic. I hope it will stimulate new research - or at least second thoughts by interested students.

Iron fertilization in the global socio-ecological system

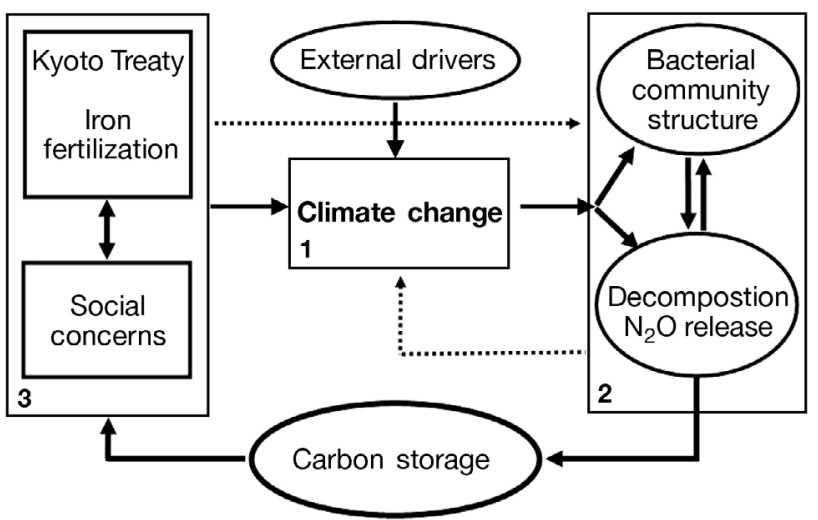

Fig. 2. The same framework as in Fig. 1, specifically showing the relationships in the socio-ecological sphere for purposeful iron fertilization of the ocean ecosystem to mitigate anthropogenic $\mathrm{CO}_{2}$ accumulation in the atmosphere. Note in both figures that there is no specified starting point for the network of feedback loops in the system 
Acknowledgements. The work for this manuscript was supported in part by NSF OPP 0217282. I thank the organizers of SAME10 for the invitation to present these ideas and David Kirchman for helpful discussions.

\section{LITERATURE CITED}

Agawin NSR, Hale MS, Rivkin RB, Matthews P, Li WKW (2006) Microbial response to a mesoscale iron enrichment in the NE Subarctic Pacific: Bacterial community composition. Deep-Sea Res II 53:2248-2267

Arrieta JM, Weinbauer MG, Lute C, Herndl GJ (2004) Response of bacterioplankton to iron fertilization in the Southern Ocean. Limnol Oceanogr 49:799-808

Azam F, Malfatti F (2007) Microbial structuring of marine ecosystems. Nat Rev Microbiol 5:782-791

Bell T, Newman JA, Silverman BW, Turner SL, Lilley AK (2005) The contribution of species richness and composition to bacterial services. Nature 436:1157-1160

Boyd PW, Law CS, Wong C, Nojiri Y and others (2004) The decline and fate of an iron-induced subarctic phytoplankton bloom. Nature 428:549-553

Boyd PW, Jickells T, Law CS, Blain S and others (2007) Mesoscale iron enrichment experiments 1993-2005: synthesis and future directions. Science 315:612-617

Buesseler KO, Boyd PW (2003) Will ocean fertilization work? Science 300:67-68

Chisholm SW, Falkowski PG, Cullen JJ (2001) Oceans: Discrediting ocean fertilization. Science 294:309-310

Church MJ, Hutchins DA, Ducklow HW (2000) Limitation of bacterial growth by dissolved organic matter and iron in the Southern Ocean. Appl Environ Microbiol 66:455-466

Cochlan WP (2001) The heterotrophic bacterial response during a mesoscale iron enrichment experiment (IronEx II) in the eastern Equatorial Pacific Ocean. Limnol Oceanogr 46:428-435

Costanza R, d'Arge R, de Groot R, Farber S, and others(1997) The value of the world's ecosystem services and natural capital. Nature 387: 253-260

Ducklow HW, Steinberg DK, Buesseler KO (2001) Upper ocean carbon export and the biological pump. Oceanography (Wash DC) 14:50-58

Falkowski P, Scholes RJ, Boyle E, Canadell J and others (2000) The global carbon cycle: a test of our knowledge of earth as a system. Science 290:291-296

Fuhrman JA, Capone DG (1991) Possible biogeochemical consequences of ocean fertilization. Limnol Oceanogr 36: 1951-1959

Gonzalez A, Descamps-Julien B (2004) Population and community variability in randomly fluctuating environments. Oikos 106:105-116

> Griffiths BS, Ritz K, Bardgett RD, Cook R and others (2000) Ecosystem response of pasture soil communities to fumigation-induced microbial diversity reductions: an examination of the biodiversity-ecosystem function relationship. Oikos 90:279-294

Griffiths BS, Ritz K, Wheatley R, Kuan HL and others (2001) An examination of the biodiversity-ecosystem function relationship in arable soil microbial communities. Soil Biol Biochem 33:1713-1722

Hale MS, Rivkin RB, Matthews P, Agawin NSR, Li WKW (2006) Microbial response to a mesoscale iron enrichment in the NE subarctic Pacific: heterotrophic bacterial processes. Deep-Sea Res II 53:2231-2247

Hall JA, Safi K (2001) The impact of in situ Fe fertilisation on the microbial food web in the Southern Ocean. Deep-Sea
Res 48:11-12

Jiang L (2007) Negative selection effects suppress relationships between bacterial diversity and ecosystem functioning. Ecology 88:1075-1085

- Loreau M, Naeem S, Inchausti P, Bengtsson J and others (2001) Biodiversity and ecosystem functioning: current knowledge and future challenges. Science 294:804-808

Martin JH, Gordon RM, Fitzwater SE (1991) The case for iron. Limnol Oceanogr 36:1793-1802

Martin JH, Coale KH, Johnson KS, Fitzwater SE and others (1994) Testing the iron hypothesis in ecosystems of the Equatorial Pacific Ocean. Nature 371:123-129

McGrady-Steed J, Morin PJ (2000) Biodiversity, density compensation and the dynamics of populations and functional groups. Ecology 81:361-373

McGrady-Steed J, Harris PM, Morin PJ (1997) Biodiversity regulates ecosystem predictability. Nature 390:162-165

Millennium Ecosystem Assessment (2005) Ecosystems and human well-being: general synthesis. United Nations www.millenniumassessment.org/en/synthesis.aspx

Morin PJ, McGrady-Steed J (2004) Biodiversity and ecosystem functioning in aquatic microbial systems: a new analysis of temporal variation and species richnesspredictability relations. Oikos 104:458-466

> Naeem S, Li S (1997) Biodiversity enhances ecosystem reliability. Nature 390:507-509

Odum HT (1971) Environment, power, and society. Wiley, New York

Oliver JL, Barber RT, Smith WO Jr, Ducklow HW (2004) The heterotrophic bacterial response during the Southern Ocean Iron Experiment (SOFeX). Limnol Oceanogr 49: $2129-2140$

Palmer M, Bernhardt E, Chornesky E, Collins S and others (2004) Ecology: ecology for a crowded planet. Science 304: $1251-1252$

Pedros-Alio C (2006) Marine microbial diversity: can it be determined? Trends Microbiol 14:257-263

Petchey OL, McPhearson PT, Casey TM, Morin PJ (1999) Environmental warming alters food-web structure and ecosystem function. Nature 402:69-72

Petchey OL, Casey T, Jiang L, McPhearson PT, Price J (2002) Species richness, environmental fluctuations, and temporal change in total community biomass. Oikos 99:231-240

Rees AP, Nightingale PD, Owens NJP (2007) FeeP-an in-situ $\mathrm{PO}_{4}{ }^{3-}$ and $\mathrm{Fe}^{2+}$ addition experiment to waters of the subtropical north-east Atlantic. European Geosciences Union General Assembly, Vienna

> Reinthaler T, Winter C, Herndl GJ (2005) Relationship between bacterioplankton richness, respiration, and production in the southern North Sea. Appl Environ Microbiol 71:2260-2266

Sarmiento JL, Orr JC (1991) Three-dimensional simulations of the impact of Southern Ocean nutrient depletion on atmospheric $\mathrm{CO}_{2}$ and ocean chemistry. Limnol Oceanogr 36:1928-1950

Smil V (2003) The earth's biosphere: evolution, dynamics and change. MIT Press, Cambridge, MA

Sogin ML, Morrison HG, Huber JA, Welch DM and others (2006) Microbial diversity in the deep sea and the underexplored 'rare biosphere'. Proc Natl Acad Sci USA 103:12115-12120

Steiner CF, Long ZT, Krumins JA, Morin PJ (2005) Temporal stability of aquatic food webs: partitioning the effects of species diversity, species composition and enrichment. Ecol Lett 8:819-828

Steiner CF, Long ZT, Krumins JA, Morin PJ (2006) Population and community resilience $\mathrm{n}$ multitrophic communities. 
Ecology 87:996-1007

Suzuki K, Hinuma A, Saito H, Kiyosawa H, Liu H, Saino T, Tsuda A (2005) Responses of phytoplankton and heterotrophic bacteria in the northwest subarctic Pacific to in situ iron fertilization as estimated by HPLC pigment analysis and flow cytometry. Prog Oceanogr 64:167-187

Vitousek PM, Mooney HA, Lubchenco J, Melillo JM (1997) Human domination of earth's ecosystems. Science 277:

Submitted: December 3, 2007; Accepted: February 16, 2008
494-499

Wohl DL, Arora S, Gladstone JR (2004) Functional redundancy supports biodiversity and ecosystem function in a closed and constant environment. Ecology 85:1534-1540 Zubkov MV, Holland RJ, Burkill PH, Croudace IW, Warwick PE (2007) Microbial abundance, activity and iron uptake in vicinity of the Crozet Isles in November 2004-January 2005. Deep-Sea Res II 54:2126-2137

Proofs received from author(s): July 7, 2008 